\title{
Rh-Catalyzed reductive Mannich-type reaction and its application towards the synthesis of ( \pm )-ezetimibe
}

\author{
Motoyuki Isoda ${ }^{1}$, Kazuyuki Sato ${ }^{1}$, Yurika Kunugi ${ }^{1}$, Satsuki Tokonishi ${ }^{1}$, Atsushi Tarui ${ }^{1}$, \\ Masaaki Omote ${ }^{* 1}$, Hideki Minami² and Akira Ando*1
}

\author{
Full Research Paper \\ Address: \\ ${ }^{1}$ Faculty of Pharmaceutical Sciences, Setsunan University 45-1, \\ Nagaotoge-cho, Hirakata, Osaka 573-0101, Japan and ${ }^{2}$ Faculty of \\ Pharmaceutical Sciences, Hiroshima International University, 5-1-1 \\ Hirokoshingai, Kure, Hiroshima 737-0112, Japan \\ Email: \\ Masaaki Omote* - omote@pharm.setsunan.ac.jp; \\ Akira Ando* - aando@pharm.setsunan.ac.jp \\ * Corresponding author \\ Keywords: \\ $\beta$-lactam; ezetimibe; reductive Mannich-type reaction; \\ rhodium-hydride; zinc enolate
}

\author{
Beilstein J. Org. Chem. 2016, 12, 1608-1615. \\ doi:10.3762/bjoc. 12.157 \\ Received: 19 May 2016 \\ Accepted: 06 July 2016 \\ Published: 27 July 2016 \\ Associate Editor: J. P. Wolfe \\ (C) 2016 Isoda et al.; licensee Beilstein-Institut. \\ License and terms: see end of document.
}

\begin{abstract}
An effective synthesis for syn- $\beta$-lactams was achieved using a Rh-catalyzed reductive Mannich-type reaction. A rhodium-hydride complex $(\mathrm{Rh}-\mathrm{H})$ derived from diethylzinc $\left(\mathrm{Et}_{2} \mathrm{Zn}\right)$ and a $\mathrm{Rh}$ catalyst was used for the 1,4-reduction of an $\alpha, \beta$-unsaturated ester to give a Reformatsky-type reagent, which in turn, reacted with an imine to give the syn- $\beta$-lactam. Additionally, the reaction was applied to the synthesis of $( \pm)$-ezetimibe, a potent $\beta$-lactamic cholesterol absorption inhibitor.
\end{abstract}

\section{Introduction}

The Mannich reaction is an important and classical $\mathrm{C}-\mathrm{C}$ bondforming reaction between an enolizable carbonyl compound and an imine to give the corresponding $\beta$-aminocarbonyl compound. For example, Shibasaki and his colleague reported the asymmetric Mannich reaction using a Lewis acid catalyst [1]. (L)-Proline is known as an excellent promoter for the Mannich reaction [2-6], and besides this, the reaction of the silyl enol ether derivatives with imines was used as an effective method [7-9]. In this situation, a wide variety of Mannich-type reactions have been reported to give $\beta$-amino esters and/or $\beta$-lactams by using metal enolates [10-17].

In contrast, most of reductive Mannich-type reactions using imines and $\alpha, \beta$-unsaturated carbonyl compounds gave $\beta$-amino esters, but there are only a few reports for a direct synthesis of $\beta$-lactams by reductive Mannich-type reactions [14,18-21]. We recently reported a reductive Mannich-type reaction using a combination of $\mathrm{RhCl}\left(\mathrm{PPh}_{3}\right)_{3}$ and $\mathrm{Et}_{2} \mathrm{Zn}$ to give the 
corresponding syn- $\beta$-lactams from $\alpha, \beta$-unsaturated esters and imines in good to excellent yields together with a small amount of the $\beta$-amino esters (Scheme 1) [22,23]. The reaction is very noteworthy because the formation of $s y n$ - $\beta$-lactams is particularly rare [24-27]. Additionally, various imines can be used for this reaction, and the corresponding $\beta$-lactams showed very high syn selectivity. However, some of the reactions using $\beta$-substituted $\alpha, \beta$-unsaturated esters did not afford the products or gave the products in very low yield (Scheme 2). Herein, we report an expansion for our previous reductive Mannich-type reaction and mechanistic studies for the stereoselectivity of this reaction. Finally the method is applied for the new synthesis of ezetimibe, a potent $\beta$-lactamic cholesterol absorption inhibitor.

\section{Results and Discussion}

First of all, we tried to solve the drawbacks of the previously reported method and found that changing the catalyst to $[\mathrm{RhCl}(\mathrm{cod})]_{2}$ greatly improved the reaction. The results from the reaction of the $[\mathrm{RhCl}(\operatorname{cod})]_{2}$ catalyst with various $\alpha, \beta$-unsaturated esters are summarized in Table 1 . Most of the synthesized $\beta$-lactams were obtained with dramatically improved yields, although the $\beta, \beta$-disubstituted $\alpha, \beta$-unsaturated ester did not give the product owing to the bulkiness of the $\beta$-position (Table 1, entries $1-8$ ). It is interesting that ethyl sorbate (2g) gave the corresponding anti- $\beta$-lactam $\mathbf{3 A g}$ in a moderate yield but with an anti- $\beta$-lactam stereochemistry indicating that the reaction proceeded via 1,6-reduction, then the resulting nucleophile was trapped by the imine at the $\alpha$-position (Table 1 , entry $9)$. By using $[\mathrm{RhCl}(\mathrm{cod})]_{2}$, the $\alpha, \beta$-unsaturated lactone was also converted to the product with a small improvement in the yield (Table 1, entry 11). Acrylamide $\mathbf{2} \mathbf{i}$ also gave the corresponding $\beta$-aminoamide $\mathbf{4 A \mathbf { i }}$ in a low yield (Table 1, entry 12).

In the reaction using $\alpha, \beta$-unsaturated lactone $\mathbf{2 h}$, the $\beta$-lactam anti-3Ah that has a hydroxy group on the side chain was obtained in a low yield (Table 1, entry 11). This result was of interest because the reaction is applicable to the synthesis of ezetimibe. Ezetimibe is an inhibitor of the cholesterol transporter Niemann-Pick C1 Like 1 Protein (NPC1L1), and is used as a strong cholesterol absorption inhibitor that reduces plasma low-density lipoprotein fraction (LDL-C) [28-30]. Recent studies on the function of NPC1L1 suggest that NPC1L1 may be involved with the internal uptake of the hepatitis $C$ virus (HCV) and absorption of vitamin K [31,32]. Although it has a simple mono $\beta$-lactamic structure and appears easy to synthesize, there are relatively few reports for the synthesis of ezetimibe because of its three asymmetric centers [33-35].

First, we examined the reaction conditions using a pilot reaction using imine 1B and 5,6-dihydro-2H-pyran-2-one (2h) (Table 2). Unfortunately, the reaction conditions as above gave a complex mixture that did not contain the desired products as shown in Table 2, entry 1 . Heating the reaction mixture at $80^{\circ} \mathrm{C}$

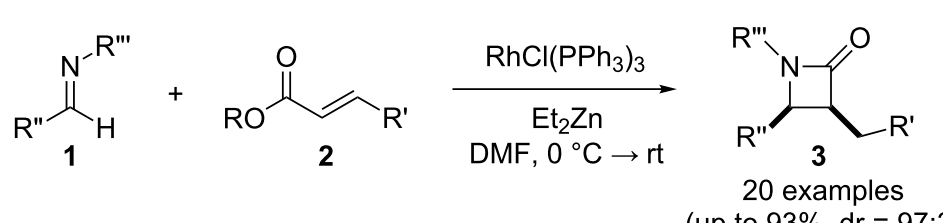

Scheme 1: The synthesis of syn- $\beta$-lactams using a reductive Mannich-type reaction.
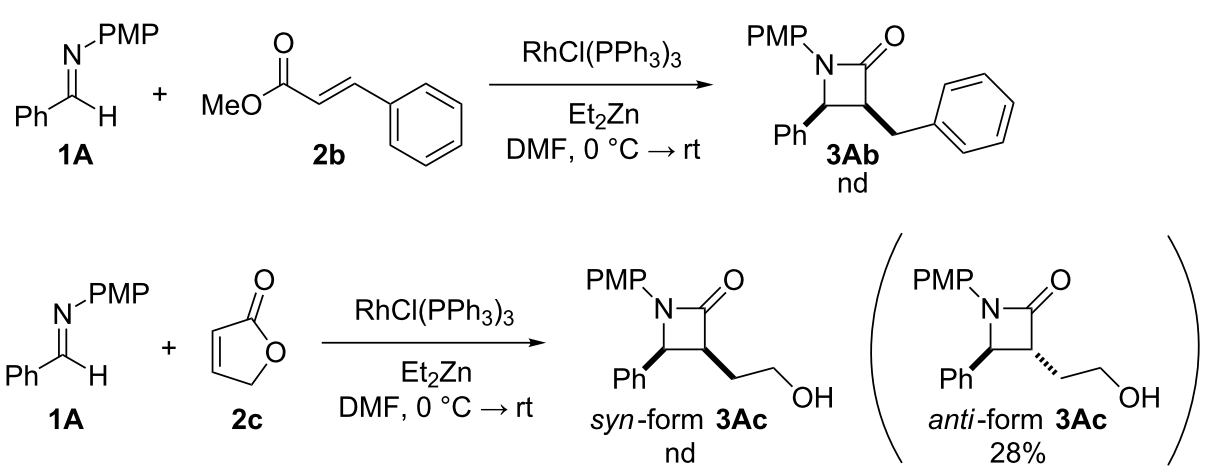
Table 1: Rh-catalyzed Mannich-type reaction using various $\alpha, \beta$-unsaturated esters.

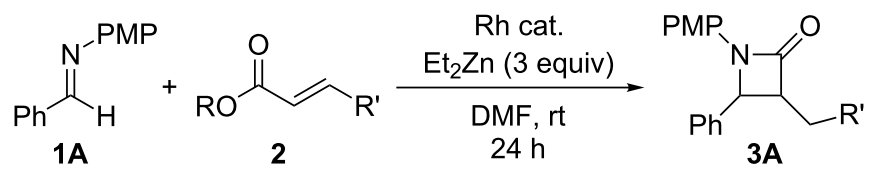

\begin{tabular}{|c|c|c|c|c|}
\hline Entry & Substrate 2 & Rh cat. (mol \%) & Product & Yield (\%) ${ }^{\mathrm{a}}$ \\
\hline 1 & ? & $\mathrm{RhCl}\left(\mathrm{PPh}_{3}\right)_{3}(2)$ & & $\begin{array}{c}88 \\
{[\text { syn/anti }=96: 4]^{b}}\end{array}$ \\
\hline 2 & $2 a$ & {$[\mathrm{RhCl}(\operatorname{cod})]_{2}(1)$} & $3 A a$ & $\begin{array}{c}78 \\
{[\text { syn/anti }=88: 12]^{b}}\end{array}$ \\
\hline 3 & & $\mathrm{RhCl}\left(\mathrm{PPh}_{3}\right)_{3}(4)$ & & nd \\
\hline 4 & $2 b$ & {$[\mathrm{RhCl}(\operatorname{cod})]_{2}(2)$} & $3 A b$ & $66^{c}$ \\
\hline 5 & & $\mathrm{RhCl}\left(\mathrm{PPh}_{3}\right)_{3}(2)$ & & $34^{c}$ \\
\hline 6 & $2 d$ & {$[\mathrm{RhCl}(\operatorname{cod})]_{2}(2)$} & 3Ad & $77^{\mathrm{c}}$ \\
\hline 7 & $2 e$ & {$[\mathrm{RhCl}(\operatorname{cod})]_{2}(2)$} & $3 A e$ & 98 \\
\hline 8 & $2 f$ & {$[\mathrm{RhCl}(\operatorname{cod})]_{2}(2)$} & 3Af & nd \\
\hline 9 & $2 \mathrm{~g}$ & {$[\mathrm{RhCl}(\operatorname{cod})]_{2}(2)$} & $3 \mathrm{Ag}$ & $\begin{array}{c}59^{d} \\
{[E / Z=93: 7]^{e}}\end{array}$ \\
\hline 10 & 0 & $\mathrm{RhCl}\left(\mathrm{PPh}_{3}\right)_{3}(2)$ & & $11^{d}$ \\
\hline 11 & $2 \mathrm{~h}$ & {$[\mathrm{RhCl}(\operatorname{cod})]_{2}(2)$} & $3 A h$ & $20^{d}$ \\
\hline 12 & $2 \mathbf{i}$ & {$[\mathrm{RhCl}(\operatorname{cod})]_{2}(2)$} & $4 \mathrm{~A}$ & $\begin{array}{c}27 \\
{[\text { syn/anti }=18: 82]^{\mathrm{b}}}\end{array}$ \\
\hline
\end{tabular}

${ }^{a}$ Isolated yield. ${ }^{b}$ Diastereomeric ratio [syn/anti] after purification. ${ }^{\mathrm{c}}$ The syn product was obtained as the sole product. ${ }^{\mathrm{d}}$ The anti product was obtained as the sole product. ${ }^{e} E / Z$ ratio by ${ }^{1} \mathrm{H} N M R$.

gave $\beta$-aminolactone $\mathbf{4 B h}$ in a very low yield (Table 2 , entry 2 ). When DME and THF were used as the solvents, the desired $\beta$-lactam was obtained in low yields (Table 2, entries 3 and 4 , respectively). We hypothesized that the low yield was caused by the instability of $\mathbf{2 h}$ and the low reactivity of imine $\mathbf{1 B}$ under the reaction conditions. Therefore, we added a Lewis acid to assist in the formation of the iminium salt in an effort to improve the reactivity. It was clear that $\mathrm{Et}_{2} \mathrm{Zn}$ was only working as a hydride source but was ineffective as the Lewis acid. Instead when zinc chloride $\left(\mathrm{ZnCl}_{2}\right)$ was added into the mixture, 
Table 2: Examination of the reaction conditions using a pilot reaction.

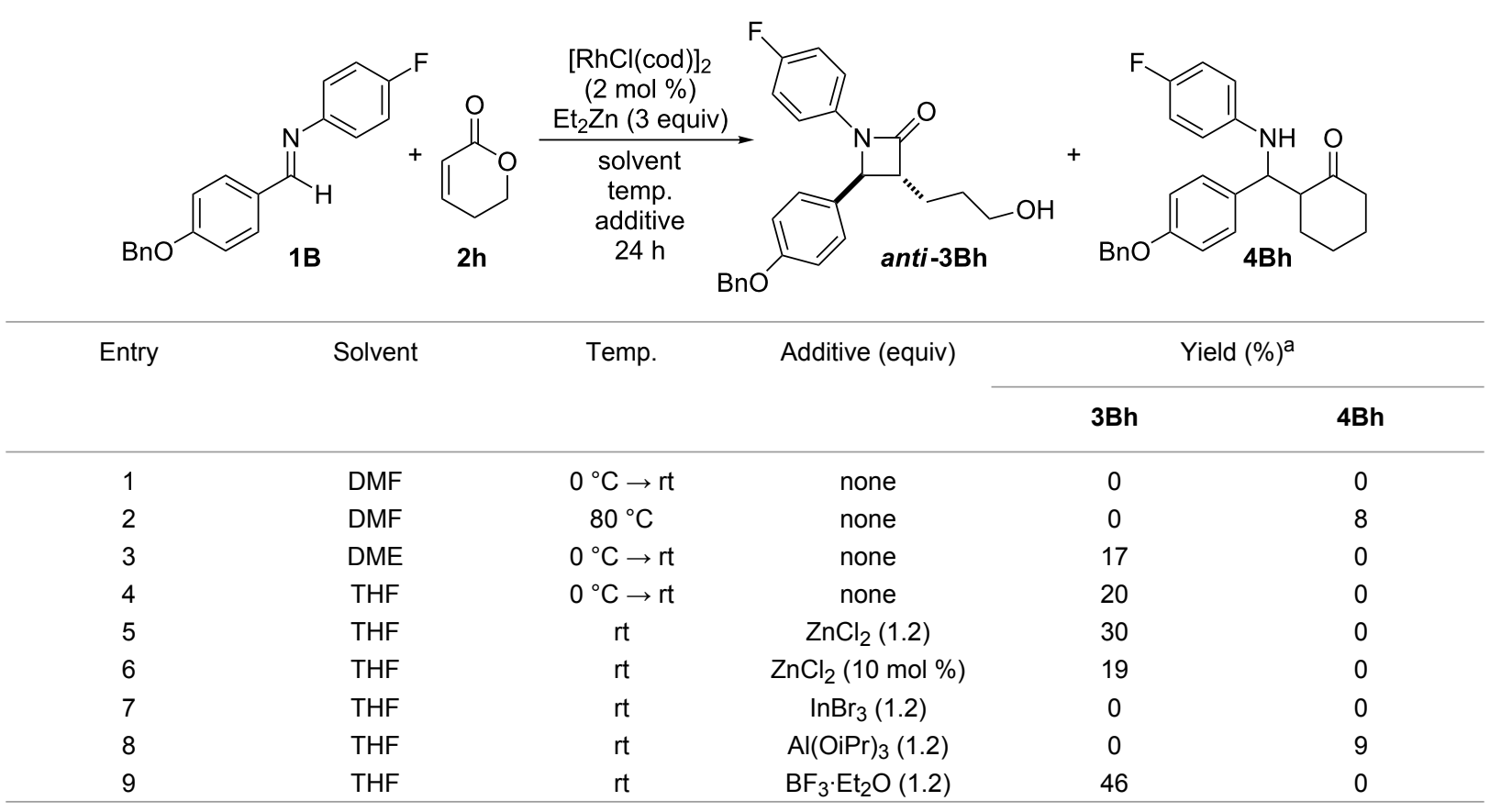

alsolated yield.

the yield was improved to $30 \%$ (Table 2 , entry 5 ). $\mathrm{BF}_{3} \cdot \mathrm{Et}_{2} \mathrm{O}$ was found to be the most suitable Lewis acid, and the desired $\beta$-lactam (anti-3Bh) was obtained in moderate yield (Table 2, entry 9).

Based on these results, we applied this reaction to the synthesis of ezetimibe (Scheme 3). The reaction of imine 1B with lactone $2 \mathbf{j}$ proceeded smoothly and gave the desired $\beta$-lactam product, anti-3Bj, in $58 \%$ yield. Fortunately, since $\mathbf{2} \mathbf{j}$ was stable com- pared to $\mathbf{2 h}$ under the reaction conditions, the yield of $\beta$-lactam anti-3Bj was somewhat improved. After deprotection using $\mathrm{Pd} / \mathrm{C}$ and $\mathrm{H}_{2}$ the target product, $( \pm$ )-ezetimibe was obtained in $80 \%$ yield and its overall yield was $46 \%$.

In some of our previous publications $[22,23,36]$, we proposed a reaction mechanism as shown in Figure 1. In the initial step, the Rh catalyst reacted with $\mathrm{Et}_{2} \mathrm{Zn}$ to give a rhodium-hydride complex 6 via the elimination of ethylene from the rhodium-ethyl

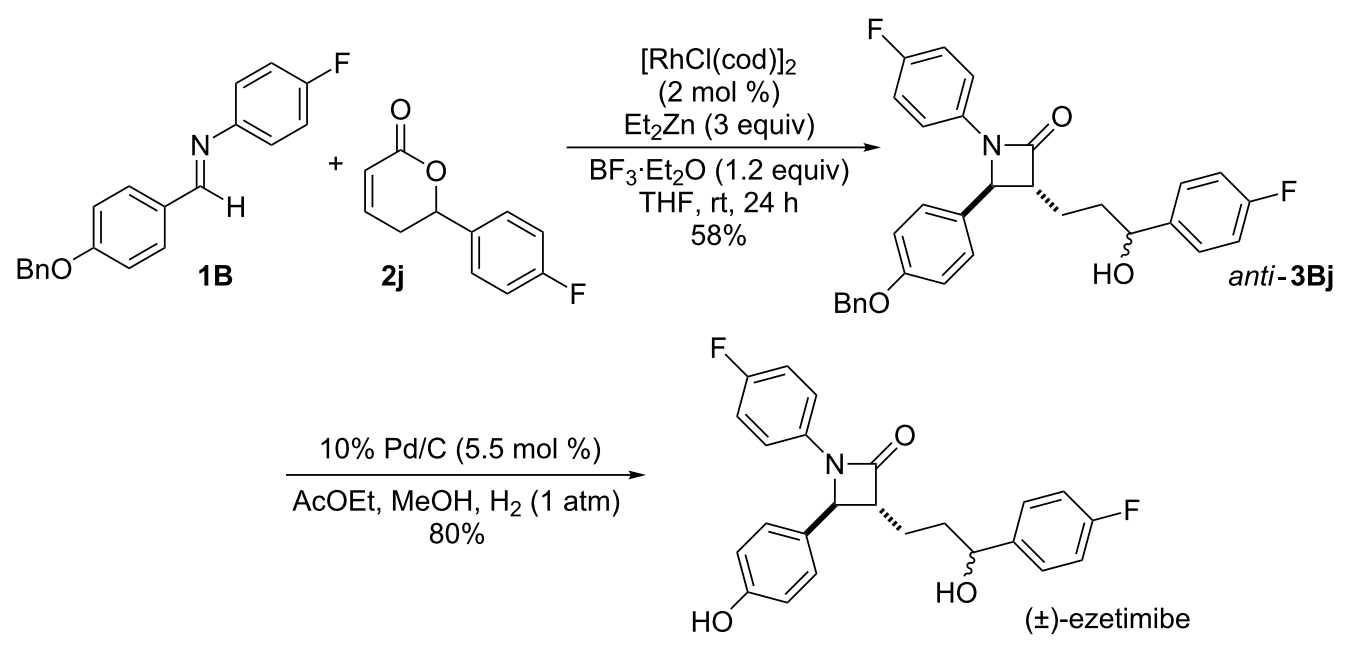




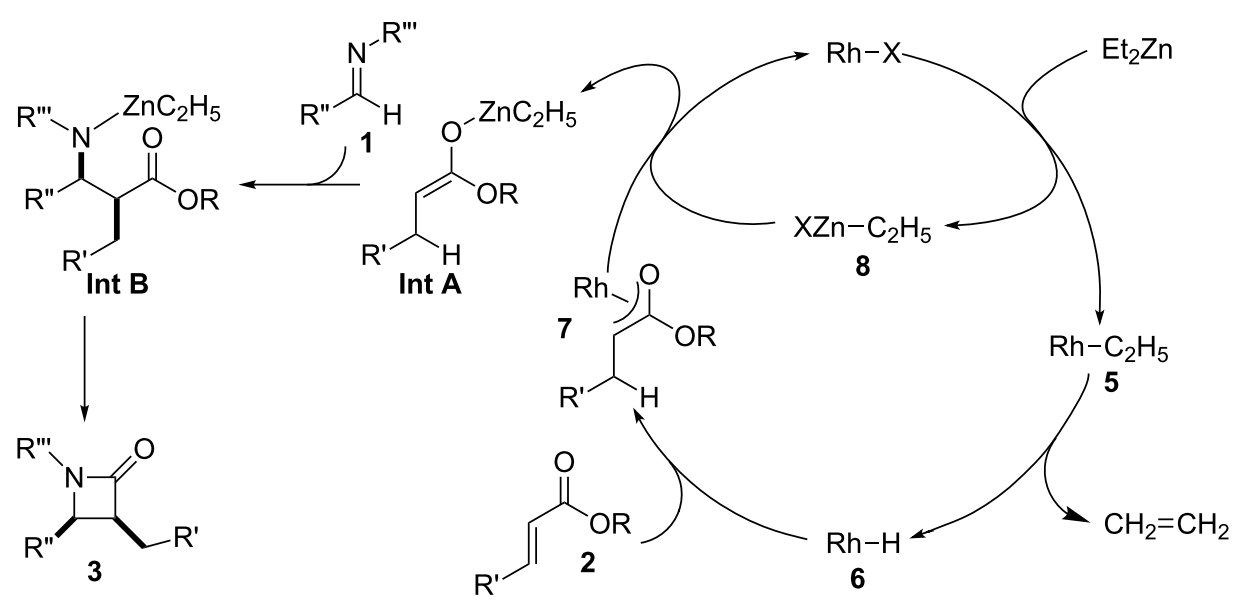

Figure 1: Plausible mechanism for the Rh-catalyzed reductive Mannich-type reaction.

complex 5. The formation of rhodium enolate 7 involved the 1,4-reduction of $\alpha, \beta$-unsaturated ester $\mathbf{2}$ by $\mathbf{6}$ and the transmetalation with a zinc species to give the Reformatsky-type reagent Int $\mathbf{A}$. This intermediate Int $\mathbf{A}$ reacts immediately with the imine to give the corresponding intermediate Int B. Subsequently, intramolecular cyclization of Int $\mathbf{B}$ gave the desired $\beta$-lactam 3. On the other hand, the possibility of alternative mechanism could not be denied which concerned with the formation of ketene from Int A to give the $\beta$-lactam, directly. However, we thought that the reaction proceeded through the above mechanism, because our previous results using similar conditions did not give the corresponding products such as $\beta$-propiolactones. It is well known that the substituents on the $\alpha$ or $\beta$-position of $\alpha, \beta$-unsaturated carbonyl compounds affect the yields and stereoselectivities [37]. A rhodium-hydride complex derived from $[\mathrm{RhCl}(\mathrm{cod})]_{2}$ seems to be suitable for the reactivity and selectivity in comparison with the corresponding rhodium-hydride complex from $\mathrm{RhCl}\left(\mathrm{PPh}_{3}\right)_{3}$ which has bulkier ligand.
The addition of a Lewis acid contributed not only to the activation the of imine but also the anti stereoselectivity of this reaction (Scheme 4). Furthermore, we reported in the previous paper that the configuration of the Int A species was identified as that of the $E$-enolate by the trapping procedure of tert-butyl acrylate (2k) with TMS-Cl. In addition, the same reaction gave only the syn- $\beta$-amino ester syn-4Ak in $86 \%$ and it was speculated that the reaction was proceeding via a linear transition state (Figure 2) [23].

When the reaction proceeded via a linear transition state, the reaction would be proposed to involve six competing transition state models (model A-F) as shown in Scheme 5. All these have steric repulsion but only the model B could be expected to have the interaction between the lone pair of the imine and the enolate metal. It seems the model B would be more stable than others to give the syn product. On the other hand, the addition of Lewis acid to the reaction mixture gave the iminium salt immediately and it would obstruct the stabilized metal interac-

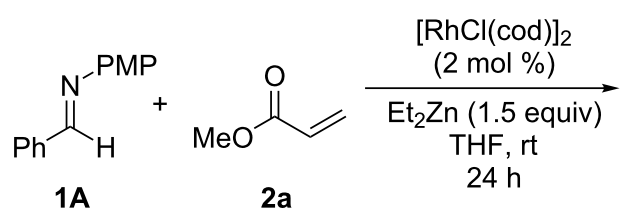<smiles>CC1C(=O)N([R16]#N)C1c1ccccc1</smiles>

$62 \%$

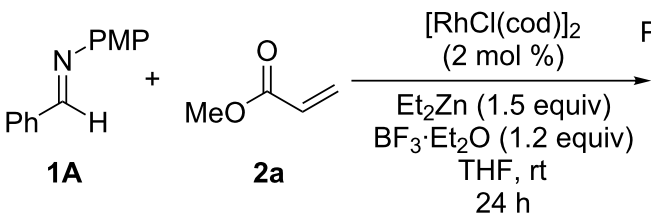

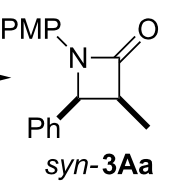

$25 \%$<smiles>C[C@@H]1C(=O)N([R16]#N)C1c1ccccc1</smiles>

$0 \%$<smiles>C[C@@H]1C(=O)N([R16]#N)[C@H]1c1ccccc1</smiles>

$37 \%$<smiles>COC(=O)C(C)C(NP=N)c1ccccc1</smiles><smiles>COC(=O)C(C)C(NC(C)(C)C)c1ccccc1</smiles> 


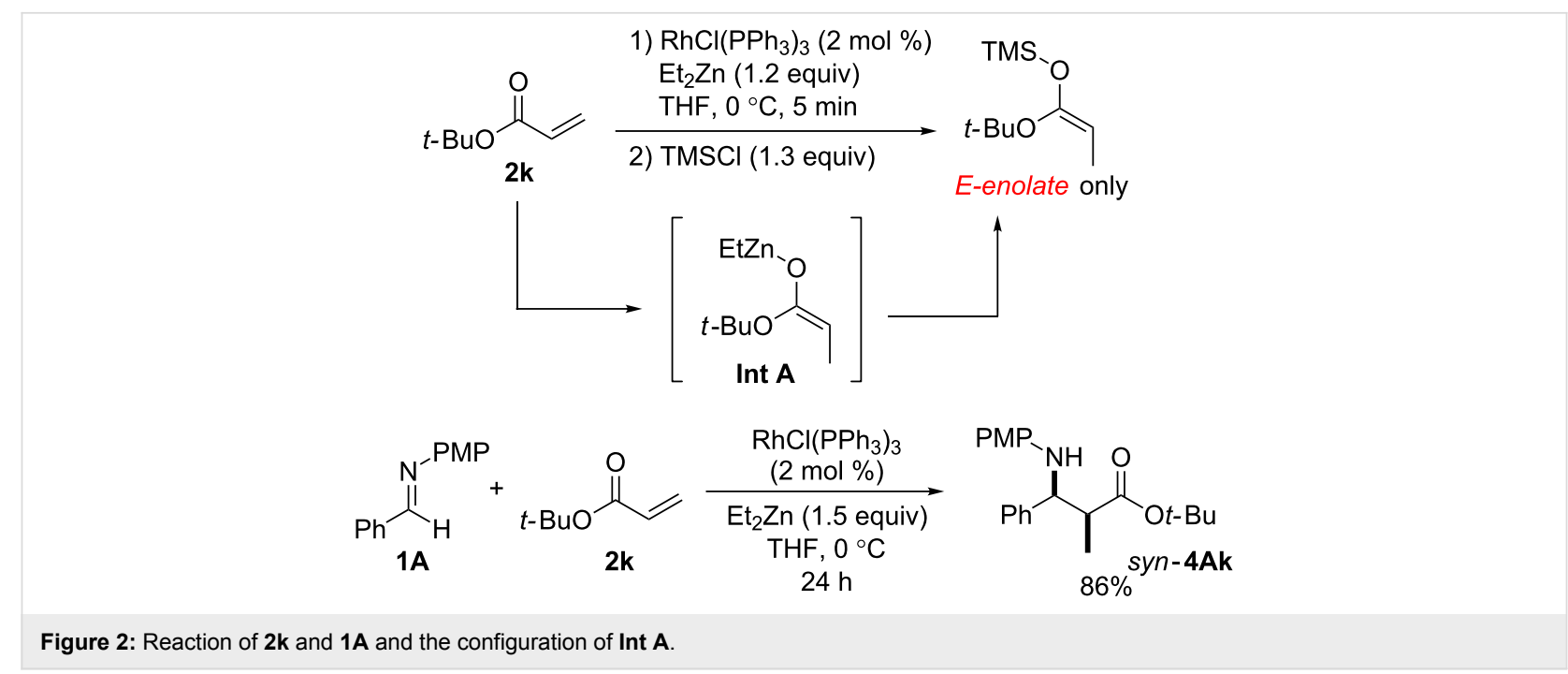

gure 2: Reaction of $\mathbf{2 k}$ and $\mathbf{1 A}$ and the configuration of Int $\mathbf{A}$

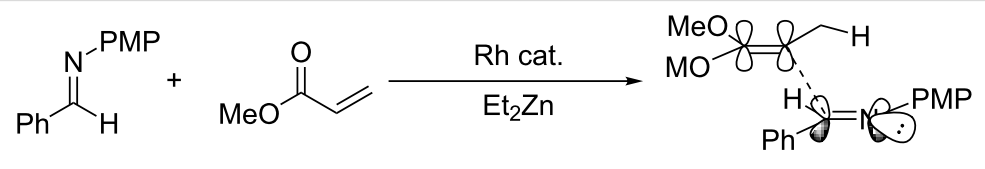

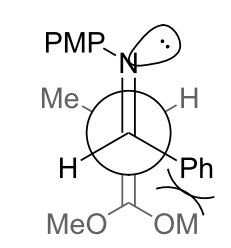

A

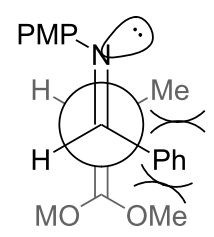

D

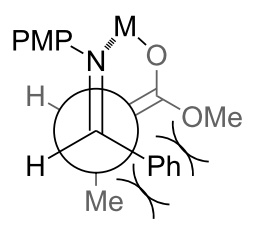

B

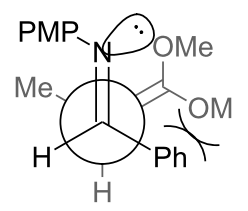

E

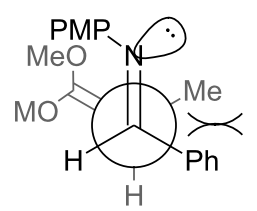

C

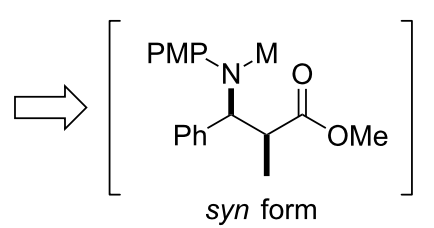

syn form

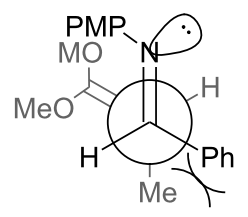

$\mathrm{F}$

Scheme 5: Transition-state model without Lewis acid.

tion in model B' of Scheme 6. This is meaning that the model F' would be the most stable model, and the formation of the anti form product might increase relatively.

\section{Conclusion}

In conclusion, we found improved conditions for reductive Mannich-type reaction using $[\mathrm{RhCl}(\mathrm{cod})]_{2}$ with $\mathrm{Et}_{2} \mathrm{Zn}$, and the reaction proceeded smoothly to give various syn- $\beta$-lactams even if $\beta$-substituted $\alpha, \beta$-unsaturated esters were employed as the substrates. In addition, we could also provide some perspectives on the reaction mechanism and the stereochemistry. When the reaction was carried out with imines and $\alpha, \beta$-unsaturated lactones, similar $\beta$-lactams with anti-selectivities were obtained. Furthermore the yield and anti selectivity could be increased by adding Lewis acid, and we succeeded in achieving the effective synthesis of $( \pm)$-ezetimibe by using this reaction.

\section{Experimental General information}

${ }^{1} \mathrm{H}$ NMR and ${ }^{13} \mathrm{C}$ NMR spectra were recorded on JNM-GX400 spectrometers and ECZS-400 spectrometers. ${ }^{19} \mathrm{~F}$ NMR spectra were recorded on Hitachi FT-NMR R-90H spectrometers. Chemical shifts of ${ }^{1} \mathrm{H}$ NMR and ${ }^{13} \mathrm{C}$ NMR are reported in ppm from tetramethylsilane (TMS) as an internal standard. Chemical shifts of ${ }^{19} \mathrm{~F}$ NMR are reported in ppm from benzotrifluoride (BTF) as an internal standard. All data are reported with the chemical shift(s), relative integration value, multiplicity ( $\mathrm{s}=$ singlet, $\mathrm{d}=$ doublet, $\mathrm{t}=$ triplet, $\mathrm{q}=$ quartet, $\mathrm{br}=$ broad, 


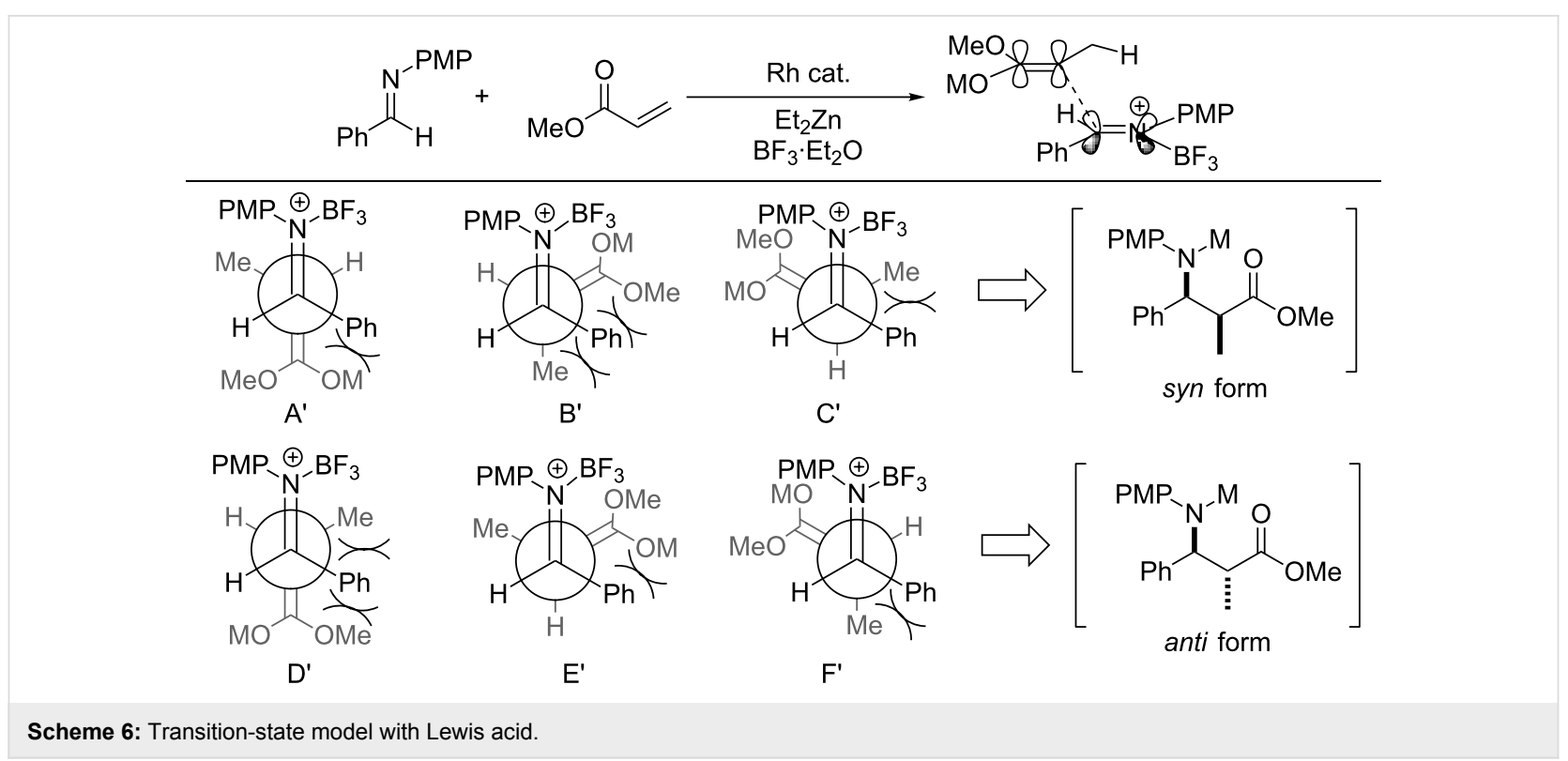

$\mathrm{m}=$ multiplet), and coupling constants $(\mathrm{Hz})$. Mass spectra were obtained on JEOL JMS-700T spectrometers. IR spectra were recorded on a Hitachi 270-30 infrared spectrophotometer. Melting points were measured on a Yanagimoto micro melting point apparatus MP-S3. Analytical gas-liquid chromatography (GLC) was carried out on a Hitachi G-3500 gas chromatograph (column; TC-5 $0.25 \mathrm{~mm} \times 15 \mathrm{~m}$, carrier; He). Peak areas were calculated on a Hitachi D-2500 Chromato-Integrator.

\section{Materials}

Tetrahydrofuran (THF) was purchased from Kanto Chemical Co. Inc. (Tokyo, Japan) in the dehydrated form. $N, N$-Dimethylformamide (DMF) and dichloromethane $\left(\mathrm{CH}_{2} \mathrm{Cl}_{2}\right)$ were distilled over $\mathrm{CaH}_{2}$ and phosphorus pentoxide directly before use, respectively. All imines were prepared from corresponding aldehydes and amines. Methyl acrylate was distilled directly before use. Other commercially available reagents were used without further purification. All experiments were carried out under an argon atmosphere in flame-dried glassware using standard inert techniques for introducing reagents and solvents unless otherwise noted.

\section{General procedure for the syn selective synthesis of azetidin-2-one}

In a manner closely related to a procedure in reference [23]: Imine (1) and $\alpha, \beta$-unsaturated ester (2,2 equiv) were added to a solution of $2 \mathrm{~mol} \%$ of $[\mathrm{RhCl}(\operatorname{cod})]_{2}$ in $\mathrm{DMF}$ at $0{ }^{\circ} \mathrm{C}$. Then, 1.0 $\mathrm{M} \mathrm{Et}_{2} \mathrm{Zn}$ in hexane (3 equiv) was gradually added to the mixture at room temperature, and the mixture was stirred for $24 \mathrm{~h}$. The mixture was quenched with sat. $\mathrm{NH}_{4} \mathrm{Cl}$ and extracted with AcOEt. The AcOEt layer was washed with sat. $\mathrm{NaCl}$ and dried over $\mathrm{MgSO}_{4}$. The solvent was removed in vacuo, and the residue was purified by column chromatography to give the corresponding syn-azetidin-2-one. The stereochemistry of the products were determined by the NOE between the $\mathrm{CH}_{3}$ and $\mathrm{C}_{6} \mathrm{H}_{5}$ groups on the azetidin-2-one ring and the coupling constant between each proton of $\mathrm{C} 3$ and $\mathrm{C} 4$ (syn form: $J=5.0-6.0 \mathrm{~Hz}$, anti form: $J=2.0-3.0 \mathrm{~Hz}$ ).

\section{General procedure for the anti selective synthesis of azetidin-2-one by the addition of $\mathrm{BF}_{3} \cdot \mathrm{Et}_{2} \mathrm{O}$}

To a solution of $[\mathrm{RhCl}(\mathrm{cod})]_{2}(2 \mathrm{~mol} \%)$ in $\mathrm{DMF}$ at room temperature was added imine (1). Then, $\mathrm{BF}_{3} \cdot \mathrm{Et}_{2} \mathrm{O}$ (1.2 equiv) was added to the mixture and stirred for $30 \mathrm{~min}$ at the same temperature. Subsequently, 5,6-dihydro- $2 \mathrm{H}$-pyran-2-one (2, 1.2 equiv) was added to the mixture and then $1.0 \mathrm{M} \mathrm{Et}_{2} \mathrm{Zn}$ in hexane (3 equiv) was gradually added to the mixture at room temperature, and the mixture was stirred for $24 \mathrm{~h}$. The mixture was quenched with sat. $\mathrm{NH}_{4} \mathrm{Cl}$ and extracted with AcOEt. The AcOEt layer was washed with sat. $\mathrm{NaCl}$ and dried over $\mathrm{MgSO}_{4}$. The solvent was removed in vacuo, and the residue was purified by column chromatography to give the corresponding antiazetidin-2-one.

\section{Supporting Information}

\section{Supporting Information File 1}

Experimental details, characterization of the compounds,

X-ray crystallographic analysis of anti-3Ai, and ${ }^{1} \mathrm{H}$,

${ }^{13} \mathrm{C}$ NMR spectra.

[http://www.beilstein-journals.org/bjoc/content/ supplementary/1860-5397-12-157-S1.pdf] 


\section{References}

1. Yamasaki, S.; lida, T.; Shibasaki, M. Tetrahedron Lett. 1999, 40, 307-310. doi:10.1016/S0040-4039(98)02297-7

2. Liu, M.; Sibi, M. P. Tetrahedron 2002, 58, 7991-8035. doi:10.1016/S0040-4020(02)00991-2

3. Taggi, A. E.; Hafez, A. M.; Lectka, T. Acc. Chem. Res. 2003, 36, 10-19. doi:10.1021/ar020137p

4. Córdova, A. Acc. Chem. Res. 2004, 37, 102-112. doi:10.1021/ar030231।

5. Notz, W.; Tanaka, F.; Barbas, C. F., III. Acc. Chem. Res. 2004, 37, 580-591. doi:10.1021/ar0300468

6. Córdova, A. Chem. - Eur. J. 2004, 10, 1987-1997. doi:10.1002/chem.200305646

7. Jacobsen, M. F.; Ionita, L.; Skrydstrup, T. J. Org. Chem. 2004, 69, 4792-4796. doi:10.1021/jo0358170

8. Hamada, T.; Manabe, K.; Kobayashi, S. J. Am. Chem. Soc. 2004, 126, 7768-7769. doi:10.1021/ja048607t

9. Ihori, Y.; Yamashita, Y.; Ishitani, H.; Kobayashi, S. J. Am. Chem. Soc. 2005, 127, 15528-15535. doi:10.1021/ja053524d

10. Nishiwaki, N.; Knudsen, K. R.; Gothelf, K. V.; Jørgensen, K. A. Angew. Chem., Int. Ed. 2001, 40, 2992-2995. doi:10.1002/1521-3773(20010817)40:16<2992::AID-ANIE2992>3.0.CO ;2-3

11. Rao, I. N.; Prabhakaran, E. N.; Das, S. K.; Iqbal, J. J. Org. Chem. 2003, 68, 4079-4082. doi:10.1021/jo020559c

12. Li, Z.; Li, C.-J. J. Am. Chem. Soc. 2005, 127, 3672-3673. doi:10.1021/ja050058j

13. Suto, Y.; Kanai, M.; Shibasaki, M. J. Am. Chem. Soc. 2007, 129, 500-501. doi:10.1021/ja068226a

14. Prieto, O.; Lam, H. W. Org. Biomol. Chem. 2008, 6, 55-57. doi:10.1039/B715839D

15. Youn, S. W.; Song, J.-H.; Jung, D.-I. J. Org. Chem. 2008, 73, 5658-5661. doi:10.1021/jo800914c

16. Jiang, J.; Xu, H.-D.; Xi, J.-B.; Ren, B.-Y.; Lv, F.-P.; Guo, X.; Jiang, L.-Q.; Zhang, Z.-Y.; Hu, W.-H. J. Am. Chem. Soc. 2011, 133, 8428-8431. doi:10.1021/ja201589k

17. Zhang, H.-X.; Nie, J.; Cai, H.; Ma, J.-A. Org. Lett. 2014, 16, 2542-2545. doi:10.1021/ol500929d

18. Palomo, C.; Aizpurua, J. M.; Gracenea, J. J. J. Org. Chem. 1999, 64, 1693-1698. doi:10.1021/jo981574d

19. Townes, J. A.; Evans, M. A.; Queffelec, J.; Taylor, S. J.; Morken, J. P. Org. Lett. 2002, 4, 2537-2540. doi:10.1021/ol020106u

20. Nishiyama, H.; Ishikawa, J.; Shiomi, T. Tetrahedron Lett. 2007, 48, 7841-7844. doi:10.1016/j.tetlet.2007.08.135

21. Du, Y.; Xu, L.-W.; Shimizu, Y.; Oisaki, K.; Kanai, M.; Shibasaki, M. J. Am. Chem. Soc. 2008, 130, 16146-16147. doi:10.1021/ja8069727

22. Sato, K.; Isoda, M.; Ohata, S.; Morita, S.; Tarui, A.; Omote, M.; Kumadaki, I.; Ando, A. Adv. Synth. Catal. 2012, 354, 510-514. doi:10.1002/adsc.201100463

23. Isoda, M.; Sato, K.; Funakoshi, M.; Omote, M.; Tarui, A.; Omote, M.; Ando, A. J. Org. Chem. 2015, 80, 8398-8405. doi:10.1021/acs.joc.5b01233

24. Taggi, A. E.; Hafez, A. M.; Wack, H.; Young, B.; Ferraris, D.; Lectka, T. J. Am. Chem. Soc. 2002, 124, 6626-6635. doi:10.1021/ja0258226

25. Chen, L.; Zhao, G.; Ding, Y. Tetrahedron Lett. 2003, 44, 2611-2614. doi:10.1016/S0040-4039(03)00187-4

26. Wang, Y.; Liang, Y.; Jiao, L.; Du, D.-M.; Xu, J. J. Org. Chem. 2006, 71, 6983-6990. doi:10.1021/jo0611521

27. Jiao, L.; Liang, Y.; Xu, J. J. Am. Chem. Soc. 2006, 128, 6060-6069. doi:10.1021/ja056711k
28. Clader, J. W.; Burnett, D. A.; Caplen, M. A.; Domalski, M. F.; Dugar, S.; Vaccaro, W.; Sher, R.; Browne, M. E.; Zhao, H.; Burrier, R. E.; Salisbury, B.; Davis, H. R., Jr. J. Med. Chem. 1996, 39, 3684-3693. doi:10.1021/jm960405n

29. Rosenblum, S. B.; Huynh, T.; Afonso, A.; Davis, H. R., Jr.; Yumibe, N.; Clader, J. W.; Burnett, D. A. J. Med. Chem. 1998, 41, 973-980. doi:10.1021/jm970701f

30. Clader, J. W. J. Med. Chem. 2004, 47, 1-9. doi:10.1021/jm030283g

31. Sainz, B., Jr.; Barretto, N.; Martin, D. N.; Hiraga, N.; Imamura, M.; Hussain, S.; Marsh, K. A.; Yu, X.; Chayama, K.; Alrefai, W. A.; Uprichard, S. L. Nat. Med. 2012, 18, 281-285. doi:10.1038/nm.2581

32. Takada, T.; Yamanashi, Y.; Konishi, K.; Yamamoto, T.; Toyoda, Y.; Masuo, Y.; Yamamoto, H.; Suzuki, H. Sci. Transl. Med. 2015, 7, 275ra23. doi:10.1126/scitransImed.3010329

33. Kværnø, L.; Werder, M.; Hauser, H.; Carreira, E. M. J. Med. Chem. 2005, 48, 6035-6053. doi:10.1021/jm050422p

34. Michalak, M.; Stodulski, M.; Stecko, S.; Mames, A.; Panfil, I.; Soluch, M.; Furman, B.; Chmielewski, M. J. Org. Chem. 2011, 76, 6931-6936. doi:10.1021/jo2010846

35. Śnieżek, M.; Stecko, S.; Panfil, I.; Furman, B.; Chmielewski, M. J. Org. Chem. 2013, 78, 7048-7057. doi:10.1021/jo400807c

36. Isoda, M.; Sato, K.; Tokura, Y.; Tarui, A.; Omote, M.; Ando, A. Chem. Pharm. Bull. 2014, 62, 956-961. doi:10.1248/cpb.c14-00223

37. Noyori, R.; Umeda, I.; Ishigami, T. J. Org. Chem. 1972, 10, 1542-1545. doi:10.1021/jo00975a017

\section{License and Terms}

This is an Open Access article under the terms of the Creative Commons Attribution License (http://creativecommons.org/licenses/by/2.0), which permits unrestricted use, distribution, and reproduction in any medium, provided the original work is properly cited.

The license is subject to the Beilstein Journal of Organic Chemistry terms and conditions:

(http://www.beilstein-journals.org/bjoc)

The definitive version of this article is the electronic one which can be found at: doi:10.3762/bjoc. 12.157 